\title{
Carlos de Pablos-Ortega* Directive Speech Acts in English and Spanish Filmspeak
}

https://doi.org/10.1515/soprag-2020-0001

Published online July 8, 2020

Abstract: The main aim of the study is to ascertain contrastively, in English and Spanish, how directive speech acts are represented in film discourse. For the purpose of the investigation, the directive speech acts of 24 films, 12 in English and 12 in Spanish, were extracted and analysed. A classification taxonomy, inspired by previous research, was created in order to categorize the different types of directive speech acts and determine their level of (in)directness. The results show that indirectness is more widely represented in the English than in the Spanish film scripts, thus confirming the assertion that being indirect is a distinctive feature of English native speakers (Grundy, 2008). This research makes a valuable contribution to the exploration of speech acts in filmspeak and informs the existing local grammar descriptions of the linguistic patterns of directive speech acts.

Keywords: directive speech acts; film discourse; directness; indirectness; mitigation

Resumen: El objetivo central de este estudio es determinar, de forma contrastiva entre el inglés y el español, cómo están representados los actos de habla directivos en el discurso cinematográfico. Para llevar a cabo esta investigación, se extrajeron y se analizaron los actos de habla directivos de veinticuatro películas, doce en inglés y doce en español. Con el fin de categorizar los diferentes tipos de actos de habla directivos y determinar su grado de (in)dirección, se creó una taxonomía de clasificación, inspirada en investigaciones previas. Los resultados muestran que el grado de (in)dirección está más ampliamente representado en el discurso cinematográfico en inglés que en español, lo que confirma la afirmación de que ser indirecto es una característica distintiva de los hablantes nativos de inglés

*Corresponding autor: Carlos de Pablos-Ortega, School of Politics, Philosophy, Language and Communication Studies, University of East Anglia, Norwich, Norfolk, UK,

E-mail: c.de-pablos@uea.ac.uk

2 Open Access. ( 2020 Carlos de Pablos-Ortega, published by De Gruyter. (c) BY-NC-ND This work is licensed under the Creative Commons Attribution-NonCommercial-NoDerivatives 4.0 International License. 
(Grundy, 2008). Este trabajo contribuye significativamente a la investigación de los actos de habla en el discurso cinematográfico y sirve para complementar las descripciones ya existentes de los patrones lingüisticos de los actos de habla directivos.

Palabras clave: actos de habla directivos, discurso cinematográfico, grado de dirección, grado de indirección, mitigación

\section{Introduction}

This paper investigates the representation of directive speech acts (DSAs) in film scripts contrastively. The two main objectives of the study are 1) to investigate the linguistic and pragmatic representation of DSA in British English and Peninsular Spanish films; 2) to analyse contrastively how DSA are performed in British English and Spanish, focussing on the level of directness of the DSA. The overall aim of this investigation is to gain an insight into the representation of DSA analysing, for that purpose, interactions in cinematic text. This research contributes to the on-going development of corpus pragmatics and local grammars (Barnbrook, 2002): an alternative approach to general grammars which helps provide a description of language in use. More specifically, as Su (2017) points out, the elaboration of local grammars of speech acts helps establish the connection between linguistic forms and their communicative function. This is an invaluable tool for researchers and scholars as it allows them to ascertain the linguistic features of speech acts in conversational exchanges.

It has been argued that dialogues seem to lack the spontaneity of naturally occurring speech and, as a consequence, the fictional value of films scripts as a linguistic research corpus has been questioned (Alvarez-Pereyre, 2011). However, film dialogues are the result of a linguistic activity carried out by script writers and they are produced by the characters' activity of speaking. In spite of much debate on this topic, in this paper we agree with Alvarez-Pereyre (2011) that tele-cinematic discourse provides highly suitable linguistic specimens, thanks to its particular combination of spoken grammar and normalized texture.

Along with the concept of film discourse, the term filmspeak has also been used to describe the way in which people are made to speak in films (AlvarezPereyre, 2011). It has been argued that despite the fact that filmspeak and film discourse can be regarded as artificial, they are a genre in their own right and both are a representation of how communication takes place between human beings. In his discussion, Alvarez-Pereyre (2011) claims that films can prove useful for 
linguistic research because they provide acceptable facts of language and a pool of utterances that have been validated by native speakers. The interference of extralinguistic elements in films can actually be beneficial because they often shed useful metalinguistic light on the facts of language and its use. Moreover, elements from the cinematic apparatus can provide useful clues on the relationship between the form, meaning and functions of lexicogrammatical structures. The use of film helps to analyse the structural-functional system of the language and to tackle linguistic-pragmatic strategies in dialogue. Similarly, films may be used to carry out quantitative analyses, especially regarding linguistic structures. Although the results of these analyses cannot be straightforwardly extended to spontaneous interactions, scripted dialogues are based on real-life interactions and some may equally be inspired by real-life interactions.

This investigation contributes to the small, but growing, number of studies in the field of applied linguistics that explore speech acts contrastively, using film discourse as a corpus of analysis.

There is a wide range of linguistic resources to produce DSAs. My hypothesis is that the English language comprises more varied linguistic resources to produce DSAs than Spanish. This would imply the use of more strategies for performing these speech acts, such as mitigation, thus providing a range of illocutionary forces. Conversely, the realization of DSAs in Spanish would be carried out using a more limited variety of linguistic resources as well as a less frequent use of mitigation devices.

In this paper, Section 2 presents the two main components of the study: DSAs and film discourse. It also provides an overview of the research carried out in the area of directives, starting from more general to more specific works, and it includes research that explores speech acts using as a corpus for the analyses the translation of film discourse via subtitling. Section 3 presents the methodological components of the study, followed by the two final sections, which are devoted to the presentation and discussion of results and the main conclusions of the study.

\section{Directive Speech Acts}

\subsection{Speech Act Theory: Directives}

As part of the speech act theory, Austin (1975) observed utterances and divided them into three different categories: locutionary acts (the production of an expression with sense and reference), illocutionary acts (the performance of the act) and the perlocutionary act (the effect produced by the performance of the act). Searle's (1969) 
development of the speech act theory, in particular the notion of the illocutionary acts, led him to create a taxonomy which includes five speech act types: declarations, representatives, expressives, commisives, and directives. Following Searle's classification of speech acts, requests are categorized as directives whose aim is to get the speaker to do something (Searle, 1969, p.11). Moreover, according to Brown and Levinson's politeness model (1987), DSAs are face-threatening acts, they make the receiver react to the speaker's utterance and take a particular action in a given situation. As a consequence, DSAs create an imposition and invade the personal space, making the receiver react to the utterance.

When performing a DSA, there are two main important variables that need to be taken into consideration: the relationship between the interlocutors, the one who performs the DSA and the receiver, and the action for which the DSA is being carried out. The relationship between the interlocutors includes two elements: social distance (whether the interlocutors know each other; i. e. family members, friends, acquaintances, etc.) and social power (the perceived power dynamic between the interlocutors).

In example 1, taken from the British film Love Actually, the interlocutors are a couple with two children. In this particular instance, the mother asks the father and the two children if she can leave the room for a moment.

Actually, do you mind if I absent myself for a second?

In this example, the DSA is a request, made by one of the interlocutors, the mother, to leave the room where the conversation with the father and the children is taking place. In this conversational exchange, there is no social distance or power between the interlocutors since they are members of a family and the reason for which the DSA is performed is the action of leaving the room. From a grammatical and syntactical viewpoint, different types of DSAs are bound to be formulated differently given the weight and importance of the reason for the realization of the DSA. As a consequence, the construction of a DSA changes according to these variables, leading to the creation of utterances which might include more (in)direct elements. For instance, when someone is requesting a large amount of money from somebody else, it is likely that the imposition of the request makes the actual formulation of the DSA more indirect. Factors other than the relationship between the interlocutors (social distance and power) and the reason for the realization of the DSA might also have an effect on the formulation of the speech act. In an emergency situation where a person is asking for help, for example, the DSA will be formulated directly given the sense of urgency; when the DSA is used repetitively, an English conductor requesting tickets on a train, the speech act is likely to be phrased using a direct construction and adding polite formulae (e. g. Tickets, please). 


\subsection{The Study of Directives in Different Languages}

Within linguistics, requesting is a speech act that has been widely researched from different angles: pragmatics and politeness, and conversation analysis. One large area of speech act research focuses on the questions used for requesting in different languages, factoring in as variables for the request the relationship between the interlocutors (social and power distance) and the action for which the DSA is carried out (Craven and Potter, 2010; González-Cruz, 2014; Lindström, 2005; Placencia, 2008; Rossi, 2015).

The investigation carried out by Curl and Drew (2008), on requests via telephone calls, factored in distance and power as main variables. A corpus of requests made by family members and out-of-hours calls to the doctor showed a difference in the distribution of modal verbs (e. g. Can you ...), and requests prefaced by I wonder if.

Another group of investigations has taken into account the relation between the interlocutors (children and caregivers) and more specifically how children choose the strategies at their disposal for getting and maintaining control of objects in the play space. These studies have been carried out in different language contexts: Polish (Ogiermann, 2015), Japanese (Takada \& Endo, 2015) and Australian English (Dixon, 2015).

Requests have also been extensively investigated in interlanguage pragmatics (Blum-Kulka \& Olshtain, 1984; Byon, 2004; Kilıçkaya, 2010; Schauer, 2006). In this area, the investigation by Usó-Juan, 2010 presents a learner-based instructional method with the aim of developing learners' sociopragmatic abilities to make request in English. From a contrastive perspective, research has also focused on the differences between English and Spanish, taking into account geographical varieties of the Spanish language (Ballesteros, 2001; Pinto, 2005; Pinto \& Raschio, 2007; Placencia, 1996). This research has looked into the issue of indirectness among native Spanish speakers tend to use more direct strategies for requesting (i. e. imperative forms). Márquez-Reiter (2000), on the other hand, investigates how speakers of English and Spanish differ in their choice of (in)directness levels, headact modifications, and the politeness types of males and females in both cultures.

Other recent research on request has examined the type of questions used when requesting (Dixon, 2015; Lindström, 2005; Ogiermann, 2015) and it has as well explored requesting forms (Curl \& Drew, 2008; González-Cruz, 2014; Heinemann, 2006; Placencia, 2008) or the linguistic forms which factor in the object for requests (Craven \& Potter, 2010; Rossi, 2015; Takada \& Endo, 2015).

Regarding the corpus of analysis, films are considered as multimodal texts since they combine different modes of communication: written texts in the screen, spoken language and moving images. An example of research on films as 
multimodal texts is the volume edited by Piazza, Bednarek and Rossi (2011) where both film and television discourse is used as a tool for the analysis of linguistic aspects. Taylor (2004, pp. 71-72) discusses how a film text is multimodal and creates meaning through other key elements besides language: images, sounds, gestures, colour, light, etc. Some of these elements are, in pragmatic terms, labelled as extralinguistic components of the language.

In the area of filmspeak and the analysis of linguistic elements, but more specifically the study of speech acts, research has been carried out in the exploration of these linguistic elements looking at the translation of speech acts via subtitling. Pedersen (2008) has looked into how speech act theory can be used for quality assessment in subtitling and other researchers have explored the representation of different types of speech acts in both subtitled and dubbed scripts: expressing compliments (Bruti, 2006), giving advice (Pinto, 2010) and the formulation of greetings, leave-taking and good wishes (Bonsignori, Bruti, \& Masi, 2011, 2012; Bonsignori \& Bruti, 2015). Other work connected with the analysis of linguistic features on the subtitles of films includes looking at the Gricean implicatures (Desilla, 2012; Greenall, 2011) and at politeness strategies (Gartzonika \& Serban, 2009). However, to date few investigations analysing speech acts in film discourse, in either one language or contrastively, have been carried out. Some studies have investigated speech acts in film scripts (Isnawati, Anam, \& Diana, 2015; Kustantini, 2012) whilst other studies have explored film scripts taking (im)politeness as the main focus of analysis (Monjour, 2006; Pacheco Baldó, 2019; Toribio \& Escolar, 2014).

Researching speech acts using film discourse as a corpus of analysis contributes to inform the existing linguistic research, relying on a type of discourse which, as previously mentioned, presents very valuable elements in language interaction. The results of this exploration will provide a complementary angle to the discipline.

\section{Methodology}

This section presents the components for the analysis, the categorization used for the classification of the DSA, the quantitative method and the structure in which the results are presented.

\subsection{Data}

For the purpose of this investigation, we have gathered a corpus of 24 films in DVD format (Table 1), divided equally into 12 British and 12 Spanish, all belonging to a 
Table 1: List of Films Used for the Analysis.

English film title and release year

Monty Python and the Holy Grail (1975)

Life of Brian (1979)

A Fish Called Wanda (1988)

Four Weddings and a Funeral (1994)

The Full Monty (1997)

Notting Hill (1999)

Billy Elliot (2000)

Calendar Girls (2003)

Love Actually (2003)

Bridget Jones Edge of Reason (2004)

The Best Exotic Marigold Hotel (2011)

About Time (2013)

\section{Spanish film title (English translation) and release year}

Mujeres al borde un ataque de nervios / Women on the Verge of a Nervous Breakdown (1988)

La comunidad / Common Wealth (2000)

El otro lado de la cama / The Other Side of the Bed (2002)

Eres mi héroe / You are my hero (2003)

Torremolinos 73 / Torremolinos 73 (2003)

Un franco, 14 pesetas / Crossing Borders (2006)

Los años desnudos / Rated X (2008)

8 citas / 8 Dates (2008)

Dieta mediterránea / Mediterranean Food (2009)

La chispa de la vida / As Luck Would Have it (2011)

Primos / Cousinhood (2011)

La gran familia española / Family United (2013)

specific film genre (comedies) and released between 1975 and 2013. This study does not take into account a longitudinal perspective (i. e. the evolution of language in film scripts from the 70s to the present day), therefore the release year is not a variable that is accounted for.

The DSAs from the film scripts were extracted from all the films and transcribed to an excel spreadsheet where they were then classified, following the proposed categorization taxonomy (see Section 3.2), and subsequently quantified, using percentages which were worked out from the total number of DSAs found in the corpus for each language. DSAs include actions such as commanding, requesting and suggesting. For the purpose of the present research, no difference was made between these types of actions. All speech acts where one interlocutor asked another to take a particular action were extracted from the corpora and factored in for the analysis. 


\subsection{Analytical Framework}

In order to analyse the DSA, the taxonomy from the CCSARP's (Cross-Cultural Study of Speech Act Realization Patterns) coding manual (Blum-Kulka, House, \& Kasper, 1989) was used. These scholars conducted research with respect to different languages, which produced a vast amount of data and, consequently, have enriched our knowledge of requests, unveiling important findings with regards to the level of (in)directness. This research conducted a cross-linguistic comparison of two speech acts (requests and apologies), based on eight languages or language varieties (Australian English, American English, British English, Canadian French, Danish, German, Hebrew and Russian). The findings provided abundant information about native speakers' patterns of realization in requests and apologies between native and non-native (native versus non-native variability) and cross-linguistically (cross-cultural variability).

For their study, the researchers developed a coding scheme which includes major categories and subcategories for the classification and realization of requests. Their categorization was divided into three different levels of directness: the most direct, the conventionally indirect and the non-conventionally indirect. In turn, these three levels were divided into nine sub-levels, called strategy types, altogether forming the scale of indirectness.

The DSAs under analysis in this paper were explored looking at three elements for the realization of the speech act: 1) the head act, the minimal unit that performs the DSA; 2) the alerters, opening utterances that precede the head act and 3) the supportive moves, external units to the DSA. These supportive moves are also known as hedging, mitigators or downtoners. The following example, taken from one of the films included in the corpus of analysis and entitled Love Actually, helps illustrate the three main elements in the realization of the DSA.

Sorry to be a bit forward and all that, but you won't have time for a Christmas drink?

This example illustrates a DSA that includes the following elements:

- an alerter: Sorry to be a bit forward and all that

- the head act: you won't have time for a Christmas drink

- mitigators: the verb in negative form (you won't have) and the adversative particle (but)

Another aspect which is included in the analysis of the DSAs is the degree or level of directness in the realization of the speech act. This aspect and the appearance of supportive moves, which are used to soften the DSAs, have been taken into account in the categorization types of head acts (Table 2). 
Table 2: Categorization Taxonomy of DSAs Including Examples from English Films.

\begin{tabular}{lll}
\hline Category of head act & Example in English & Film \\
\hline Strong Direct & Do us a favour & The Holy Grail \\
Weak Direct & Please, please, listen & The Life of Brian \\
Conventionally Indirect 1 & Can I see that? & A Fish Called Wanda \\
Conventionally Indirect 2 & I was wondering where & Four Weddings and \\
& you are staying tonight & a Funeral \\
Non-conventionally & Are you going upstairs to & Calendar Girls \\
Indirect/Hints & do your homework? & \\
\hline
\end{tabular}

With a view to creating a consistent analytical approach, a categorization taxonomy (Table 2) inspired by previous research (Blum-Kulka, House, and Kasper, 1989; Márquez-Reiter, 2000; Pinto, 2010; Searle, 1979) was created.

The first category of the head act, Strong Direct DSAs, includes the following linguistic constructions: 1) bare imperatives, which lack of visible subjects (You); 2) adverbs (Out now!); and 3) nouns, which are sometimes used for requesting (Boarding pass). The second category is Weak Direct and it includes: 1) imperatives with personal pronouns (You); 2) imperatives followed or preceded by a polite marker (Go out, please or Please go out); 3) a gerund or present participle in an interrogative form (Going out?); 4) other constructions expressing obligation (I want you to go out/I say go out); 5) instances where the first person plural imperative is used (Let's go out); and 6) the use of polite formula, such as "Please" or "Thank you". It is interesting to note the illocutionary force of thanking as a DSA, which is uncommon in other languages. This polite marker is often used in British English to thank someone before the actual request has been performed, as a way of emphasizing the illocutionary force of the DSA (De Pablos-Ortega, 2011, 2015).

The third part of the categorization taxonomy of DSA is labelled as Conventionally Indirect and has been subdivided into two further categories in order to differentiate the levels of indirectness. The first one includes structures containing modal verbs: can, could, may, might and will. The use of the modal verb turns the head act into an indirect DSA, providing hedging for the performance of the action, usually presented in the form of a question/question form: "Can you go out?", “Could you help?”, “May I have your boarding pass?”, etc. However, it might also be present in statements like "You must go out", where the DSA provides a sense of obligation. The second group of Conventionally Indirect DSAs includes other modal verbs (would, should) along with verbs and expressions whose lexical meaning denotes indirectness of the DSA. Some examples of these constructions are: "Would you like to go out?", "I wonder if you can go out", "Do you mind going 
out?”, “I'm sure you would like to go out”, "You should probably go out”, etc. The final category has been labelled as Non-conventionally Indirect or Hints and contains structures whose illocutionary force is not intended as DSA, however the contextual and extra-linguistic elements (relationship between the interlocutors, situation where the interaction is taking place, etc.) make the speech act function as directives. For example, if two interlocutors are talking indoors and one says: "It's really nice outside", this utterance can be interpreted in two ways, as a hint, implying that one of the interlocutors would like to go outside, or a statement on the weather. The sentence in this example, which is a statement of fact, has the illocutionary force of a DSA. Therefore, different linguistic structures, which might appear to perform other types of speech acts (compliments, apologies, thanking, etc.) if used in isolation, can behave with different illocutionary force, given contextual and extra-linguistic factors. It is important to bear in mind that one of the aspects which was not taken into the account in the analysis was the social and power distance between the interlocutors when the DSA was performed. Once the methodological aspects of the research have been introduced, the following section presents the results and the most significant findings of the analysis.

\section{The Representation of DSAs in English and Spanish Film Scripts}

The data analysis of the film scripts is carried out separately for each language in the first instance, and then the relevant comparisons are drawn. The results in this section are presented by film in each language and each group is then further divided into direct and indirect DSAs. Finally, the level of directness is taken into consideration.

The total number of DSAs found in both corpora is 1966, broken down into 828 DSAs for the English film scripts and 1138 DSAs for the group of Spanish films. The total length of the English films is $22 \mathrm{~h}$ and $21 \mathrm{~min}$ compared with $19 \mathrm{~h}$ and $9 \mathrm{~min}$ for the Spanish films.

One of the significant findings is the wide variety of linguistic structures used as DSAs, more specifically in the English film scripts, in contrast with the Spanish corpus (Tables 3 and 4). In order to facilitate the categorization of the different structures found in the English corpora, Table 3 includes for each category of the classification examples with two verbs: go out and have + an object (have a boarding pass). The largest number of linguistic structures corresponds with the category Conventionally Indirect 2, which includes strategies such as modal verbs, specific constructions (I wish) or any lexical items which make the DSA indirect 
Table 3: Linguistic Structures as DSAs in the English Corpus.

\begin{tabular}{l}
\hline Strong Direct \\
\hline - Out now! \\
- Go out! \\
- Boarding pass. \\
\hline Weak Direct \\
\hline - You go out. \\
- You are going out. \\
- Go out, will you? \\
- Go out please! \\
- Please, go out. \\
- Going out? \\
- I say go out \\
- Let's go out \\
- Please, please! \\
- Thank you. \\
- I want you to go out. \\
- I order you to go out. \\
- I command you to go out. \\
\hline Conventionally Indirect 1 \\
- You must go out. \\
- Will you go out? \\
- Can you go out? \\
- Can't you just go out? \\
- Could you go out? \\
- May I have your boarding pass? \\
\hline
\end{tabular}

\section{Conventionally Indirect 2}

- You couldn't go out, could you?

- You can't go out.

- Have you got your boarding pass?

- Would you like to go out?

- I wonder if you can go out?

- I wonder if you could go out?

- I wondered if you can go out?

- I wondered if you could go out?

- I look forward to you going out.

- Do you mind going out?

- Do you mind if you go out?

- Would you mind going out?

- Perhaps you can go out.

- You should probably go out.

- I'm sure you would like to go outside.

- I wish you would go out.

Non-conventionally Indirect

- It's really nice outside.

- I would go outside.

(wonder, mind, to be sure). This group is followed by Weak Direct structures, including imperatives in combination with polite markers (please), gerunds (going) and other linguistic constructions (want/order/command + you + infinitive). Conventionally Indirect 1 structures include less varied constructions as they are limited to the use of modal verbs (can, could, may, etc.). The two categories in the taxonomy which present the fewest number of structures are Strong Direct and Non-conventionally Indirect, including three and two constructions respectively.

After analysing the Spanish corpora (Table 4), the findings reveal that the largest amount of linguistic structures corresponds to Weak Direct, which includes imperatives followed by polite markers and linguistic constructions such as want + you + infinitive. A similar number of structures are part of the category Strong Direct, which present imperatives with the formal and informal you forms in Spanish (tú, usted, ustedes, vosotros/as) as well as the use of nouns (Camarero, 
Table 4: Linguistic Structures as DSAs in the Spanish Corpus.

\begin{tabular}{ll}
\hline Strong Direct & Conventionally Indirect 1 \\
\hline - Ayúdeme. & - ¿Me puedes ayudar, por favor? \\
- Ayúdame. & - ¿Me ayudarás? \\
- Ayúdennos. & - ¿Te ayudo? \\
- Camarero. & - ¿Un zumito? \\
\hline Weak Direct & Conventionally Indirect 2 \\
\hline - Ayúdeme, por favor. & - ¿Por qué no nos ayudas? \\
- Documentación, por favor. & - ¿No me vas a ayudar? \\
- Por favor. & - ¿Nos ayudas? \\
- Tranquilo. & - ¿Te importaría ayudarme? \\
- Con cuidado. & - ¿Nos ayudas por favor? \\
- Yo le ruego que me ayude. & \\
- Quiero que me ayudes. & \\
- Que me ayudes. & \\
- Si no me ayudas, no hace falta que vuelvas. & \\
\hline
\end{tabular}

"waiter") or adverbs and adverbial forms (Con cuidado, "be careful"). Both Conventionally Indirect categories, 1 and 2, comprise four and five structures respectively. The examples of Conventionally Indirect 1 forms are the modal verb can (“poder”) or the future form of the verb will you (“¿me ayudarás?”). Conventionally Indirect 2 forms comprise interrogative questions using present tense or the lexical verb form mind (“¿te importaría?”). No structures for the Non-conventionally Indirect category are found in the Spanish corpus.

A preliminary analysis of the DSAs (Figure 1) reveals that the number of direct DSAs is higher than the number of indirect DSAs in both corpora/in the whole corpus/in both languages. However, the percentage of direct DSAs is higher in Spanish (84\%) than in English (74\%) whilst the results are opposite for indirect DSAs: 26\% in English and 16\% in Spanish. Out of the total of DSAs in English (828), 216 DSAs are indirect whilst out of the total of DSAs in Spanish (1138), 150 DSAs are indirect. 


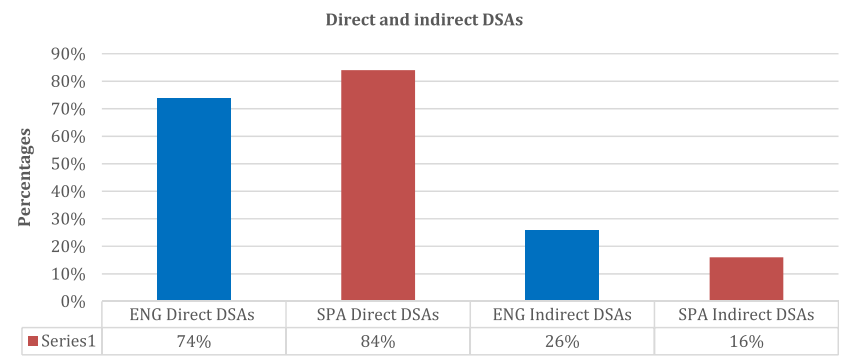

Figure 1: Direct and Indirect DSAs in English and Spanish Film Scripts.

A more detailed analysis, however, looking at the individual films in each corpus (Figure 2), shows more distinct differences between both corpora. Six of the English films include a higher number of DSAs (direct type) in their original scripts (Figure 2): Billy Elliot (91\%), The Full Monty (89\%), The Life of Brian (87\%), The Holy Grail (84\%) and Bridget Jones (84\%). The other six English films show a slightly lower representation of DSAs (direct type), showing higher percentages in the indirect type of DSAs: Four Weddings and a Funeral (52\%), Love Actually (46\%), About Time (45\%), Best Exotic Marigold Hotel (43\%), Calendar Girls (41\%) and Notting Hill (37\%). As it will be later discussed in this section, the film plots of these comedies play an important role for the inclusion of more direct or indirect types of DSAs in the film scripts. Therefore, English comedies, such as the Monty Python series (The Life of Brian and The Holy Grail), include a higher number of direct types of DSAs, whilst the group of English romantic comedies (Four Weddings and a Funeral, Notting Hill or About Time) tend to use indirect types of DSAs.

The exploration of DSAs in the Spanish film scripts (Figure 3) indicates a regular use of the direct type. All films reveal a higher percentage ( $77 \%$ or above) in

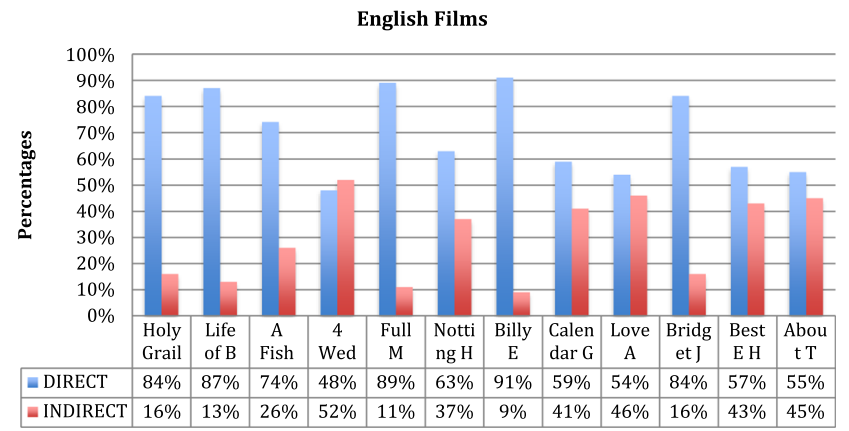

Figure 2: Representation of Direct and Indirect Types of DSAs in English Film Scripts. 


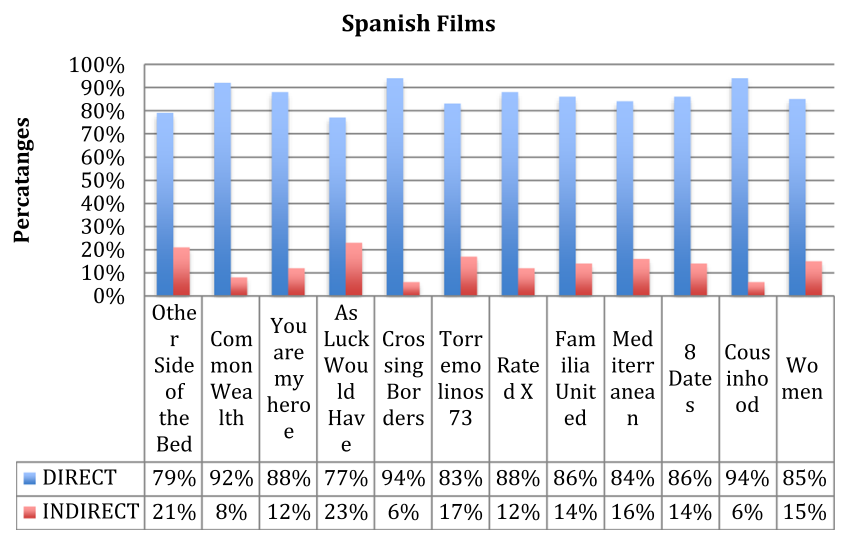

Figure 3: Representation of Direct and Indirect Types of DSAs in Spanish Film Scripts.

the use of the direct type of DSAs. In three Spanish films the percentages of the indirect type are very low: Crossing Borders (6\%), Cousinhood (6\%) and Common Wealth (8\%). These results show that the in the performance of DSAs in the Spanish language there is a tendency to use more direct than indirect formulae. In comparison with the English corpus, it is apparent that the general tendency is to use more indirect types of SDAs in English than in Spanish, thus confirming that being indirect is a distinctive feature of English native speakers (Grundy, 2008).

A more in-depth analysis of the type of DSAs was carried out in both corpora following the categorization taxonomy (Figure 4). In four of the 12 English films, Strong Direct forms (bare infinitives, adverbs or nouns) are used in more than $50 \%$ (The Holy Grail, The Life of Brian, The Full Monty and Billy Elliot). Weak Direct types

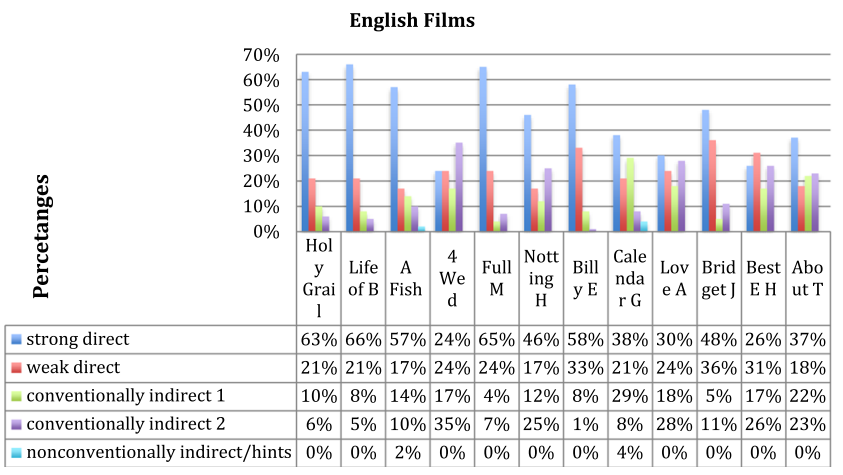

Figure 4: Type of DSAs in English Film Scripts. 
(imperatives including the pronoun you or imperatives followed by polite markers, like "please") are used in 33\% of the cases or less. These findings indicate that when using a direct type of DSAs, the preferred type is Strong versus Weak.

The analysis of the film scripts in English with a higher percentage use of Conventionally Indirect type of DSAs shows a preference for type 2 (modal verbs and expressions with verbs whose lexical meaning provides indirectness). These results are found in Four Weddings and a Funeral (35\%), Love Actually (28\%), The Best Exotic Marigold Hotel (26\%) and Notting Hill (25\%). Conventionally Indirect type 1 (modal verbs such as can, could, etc.) show a high percentage, over $20 \%$ in only two films: About Time (22\%) and Calendar Girls (29\%). Non-conventionally Indirect forms only appear in two films showing very low percentages: Calendar Girls (4\%) and A Fish Called Wanda (2\%).

The comprehensive analysis of the DSA type in the Spanish corpus (Figure 5) shows a preference for Strong Direct forms (higher than 70\%) in seven of the 12 films: Crossing Borders (91\%), Common Wealth (86\%), Rated X (76\%), Family United (72\%), Eight Dates (72\%), You Are My Hero (70\%) and Women on the Verge of Nervous Breakdown (70\%). Three films scripts reveal the highest percentages of Weak Direct type of DSAs: The Other Side of the Bed (31\%), Cousinhood (26\%) and As Luck Would Have it (20\%). The use of both types of Conventionally Indirect forms (1 and 2) in the Spanish corpus is lower than in the English corpus, showing $10 \%$ or less of this type of structures in DSAs in nine film scripts out of 12 . In the

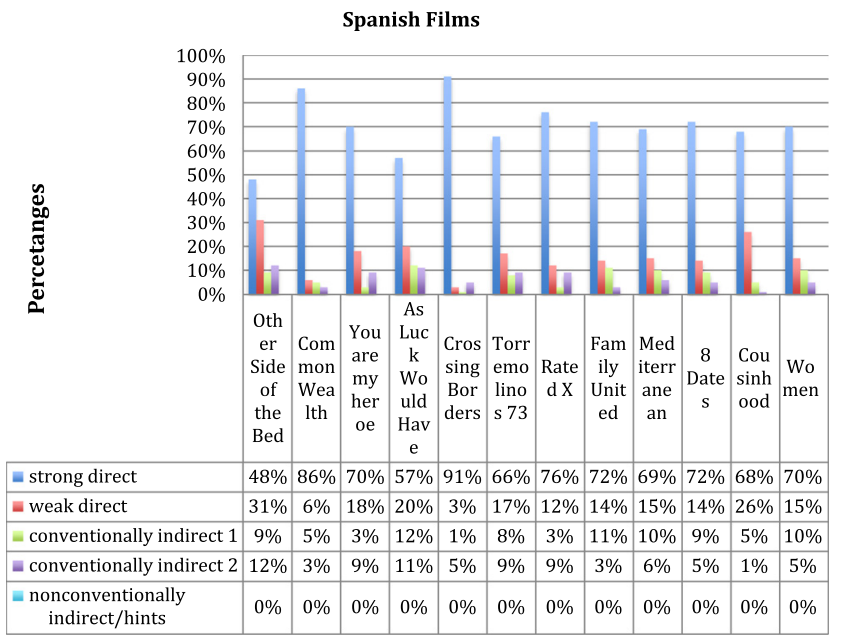

Figure 5: Type of DSAs in Spanish Film Scripts. 
Spanish film scripts, Non-Conventionally Indirect or hints are found, which is a significant factor for the representation of (in)directness in the Spanish language.

Overall, the analysis revealed significant findings for the distribution, frequency and contrasts in use between English and Spanish DSAs. There are clear differences in the number of linguistic structures of the DSA taxonomy found in each corpus (Tables 3 and 4). The variety of construction types in the English corpus is, by far, wider than in the Spanish corpus. This becomes apparent in two categories of the taxonomy: Weak Direct and Conventionally Indirect 2, where the number of linguistic structures is almost double for Weak Direct and more than triple for Conventionally Indirect 2 in the English corpus. This confirms that English comprises more varied linguistic resources to communicate similar messages and, as a consequence, more strategies to differentiate the illocutionary force of the speech acts. Conventionally Indirect 2 structures found in the English film scripts are constructions which include modal verbs in negative forms (You couldn't go out, could you? You can't go out.) or other lexical verbs in different forms (I wonder if you could go out, I wondered if you can go out?, Do you mind if you go out?, Would you mind going out?, I wish you would go out.), displaying a wide range of linguistic elements that function as mitigators for the realization of DSAs (i. e. the use of the conditional tense, the use of negative modal verbs to soften the request, etc.). The same category in the Spanish corpus only includes the present tense form ( ¿Nos ayudas?, "Do you help us?") and one construction using the verb mind (¿Te importaria ayudarme?, "Would you mind helping me?”). This result confirms that the use of mitigation is infrequent in Spanish, as previous research has shown (Bravo, 2008; Haverkate, 1990; Hernández-Flores, 1999; Flores-Ferrán, 2010; Placencia, 1996, among others). The use of more direct DSAs in Spanish has direct consequences in the perception of Spanish native speakers by English native speakers as the issue of directness is portrayed as impolite or rude (de PablosOrtega, 2010, 2015 and 2019). Conversely, the use of indirect forms in English, which are used as a facing device, might lead to a lack of clarity for Spanish speakers when DSAs are performed.

The case of the linguistic structures included in the Weak Direct category of DSAs is similar to the Conventionally Indirect category: the English language makes use of a wider selection of modal verbs (i. e. can, could, may, might) and, as a consequence, has more lexical nuances than the same verb type in the Spanish language.

From a general perspective, the use of direct forms of DSAs is more common in both corpora, showing a higher percentage in the Spanish corpus (84\%) than the English (74\%). Conversely, indirect forms of DSAs are less frequent, showing a slightly higher percentage in the English corpus (26\%) than in the Spanish (16\%). The English films Holy Grail, Life of Brian, A Fish Called Wanda, Full Monty and Billy Elliot use direct types of DSAs more frequently than the other films, Notting Hill, 
About Time, Love Actually, Four Weddings and a Funeral and The Best Exotic Marigold Hotel, which tend to use more indirect types of DSAs in their scripts. This last group of five films belong to a romantic comedy genre, as opposed to simply comedy. The film scripts of these films include more elaborate dialogues and a significant amount of more indirect formulae in linguistic structures. These are used to create humour, which is an essential part of the tone of this type of films. In addition to the film genre, it is important to point out an idiosyncratic aspect that might have influenced the use of more indirect DSAs: the fact that Richard Curtis is the scriptwriter of four of these romantic comedy films (Notting Hill, About Time, Love Actually and Four Weddings and a Funeral).

The percentage of indirect types of DSAs in the Spanish corpus is smaller in relation to the English corpus and no clear correlation between the film type and the use of indirect types of DSAs is shown. This might, in part, be due to the fact that more direct forms for the realization of speech acts are used in conversational exchanges Spanish. These results are in line with previous research where direct formulae is the preferred option when requesting in Spanish (Ballesteros, 2001; Placencia,1996; Márquez-Reiter, 2000, among others).

With regards to the different types of direct and indirect DSAs (Strong Direct, Weak Direct, Conventionally Indirect 1, Conventionally Indirect 2, Non-conventionally Indirect), the English corpus makes much wider use of all categories in comparison with the Spanish corpus. The English films Notting Hill, About Time, Love Actually, Four Weddings and a Funeral and The Best Exotic Marigold Hotel use Conventionally Indirect 2 forms more frequently than the rest of the English films from the corpus. This type of indirect form corresponds with elaborate linguistic structures using modal verbs (would, should) and expressions with verbs whose lexical meaning denotes indirectness of the DSA. Some examples of these constructions are: "Would you like to go out?", "I wonder if you can go out", "Do you mind going out?", "I'm sure you would like to go out", "You should probably go out". This is explained by the way in which the dialogues have been constructed and they reflect the type and role of the characters that take part in these films, often members of the middle and upper classes.

\section{Conclusion}

This investigation has revealed contrastively how DSAs are performed in British English and Peninsular Spanish in the linguistic representation from 24 film scripts, shedding light on the levels of directness found in selected films in both languages.

From the analysed sample of 1966 DSAs, 828 examples were found in the English corpus and 1138 in the Spanish. The analysis of DSAs in the English and 
Spanish film scripts shows that from a linguistic viewpoint, a remarkable number of linguistic structures for directives are found in both corpora, which clearly shows how speech act patterns for directives are constructed as part of the local grammar in corpus pragmatics. However, the English corpus confirms a broader use of linguistic patterns to perform DSAs in English than in Spanish.

Although both languages apparently favour direct over indirect speech acts, the contrastive analysis indicates that there is a tendency to use indirect speech acts more often in English than in Spanish. A further, significant difference in the use of direct and indirect DSAs has subsequently been discovered within the British corpus. In the films The Full Monty, Calendar Girls and Billy Elliot, which portray characters from the north of England, more use is made of direct than of indirect formulae. Conversely, another group of films (Notting Hill, About Time, Love Actually and Four Weddings and a Funeral) makes more frequent use of indirect types of DSAs. It may be argued that the high incidence of directness might be due, in part, to regional differences and/or social class, in the use of the English language. This is an area which certainly merits further exploration.

The twelve English-speaking films contain more indirect forms of DSAs than those in the Spanish-speaking corpus, which is in line with previous research on cinematic discourse carried out by Su (2017). In that investigation, requests in the transcripts of the sitcom The Big Bang Theory were analysed and a high number of these speech acts were realised indirectly, thus confirming Grundy's observation (2008) that being indirect is a distinctive feature of English native speakers. In this regard, it is worth noting that from an intercultural perspective, the use of direct and indirect forms is an issue that often leads to breakdown in communication between members with different linguistic or cultural backgrounds (Grainger and Mills, 2016: 1). This can lead to value judgements made by people from differing cultures, as is the case when, following the norms of English native speakers, Spaniards are perceived as "rude" (de Pablos-Ortega, 2010, 2011 and 2019) and in the case of Spanish native speakers, English native speakers are perceived as "distant".

This investigation contributes to the scant corpus of films used as tools for linguistic research and more specifically to research within the field of pragmatics. The use, in this case, of an original corpus for the study and exploration of pragmatic features, provides a noteworthy contribution to the field of applied linguistics.

The findings of this investigation have strong implications for those teaching the pragmatic elements of these languages to learners of both English and Spanish as foreign languages. The effect that (in)directness has upon each culture and the imposition of cultural stereotypes should not be underestimated.

This paper has provided a thorough account of the linguistic representation of DSAs from the film scripts and the subtitles of 24 films in English and Spanish. The 
substantial empirical support for the findings (1966 examples in total) sheds enough light to reach significant conclusions concerning the representation of these DSAs and contributes to the pragmatic corpus of local grammar descriptions in the teaching and learning of speech acts. Following this line of investigation, other types of speech acts could be further researched in order to develop a broader view of the linguistic representation of speech acts in audiovisual texts.

\section{References}

Alvarez-Pereyre, M. (2011). Using film as linguistic specimen: Theoretical and practical issues. In R. Piazza, M. Bednarek \& Rossi, F. (Eds.), Telecinematic discourse: Approaches to the language of films and television series (pp. 47-67). Ciudad: Editorial.

Austin, J. L. (1975). How to do things with words. Oxford: Clarendon.

Ballesteros Martín, F. (2001). La Cortesía Española Frente a La Cortesía Inglesa. Estudio Pragmalingüístico de Las Exhortaciones Impositivas. Estudios Ingleses de La Universidad Complutense, 9, (pp. 171-208).

Barnbrook, G. (2002). Defining language. A local grammar of definition sentences. Studies in corpus linguistics. 11. Amsterdam: John Benjamins Publishing Company.

Blum-Kulka, S., House, J., \& Kasper, G. (1989). Cross-cultural pragmatics, speech acts, politeness. Norwood, NJ: Ablex.

Blum-Kulka, S., \& Olshtain, E. (1984). Requests and apologies: A cross-cultural study of speech act realization patterns (CCSARP). Applied Linguistics, 5(3), 196-213.

Bonsignori, V., \& Bruti, S. (2015). Conversational routines across languages: The case of greetings and leave-takings in original and dubbed films. In J. Díaz-Cintas, \& J. Neves (Eds.),

Audiovisual translation: Taking stock (pp. 28-45). Newcastle upon Tyne: Cambridge Scholars Publishing.

Bonsignori, V., Bruti, S., \& Masi, S. (2011). Formulae across languages: English greetings, leavetakings and good wishes in dubbed Italian. In J. M. Lavaur, A. Matamala, \& A. Serban (Eds.), Audiovisual translation in close-up: Practical and theoretical approaches (pp. 23-44). Bern: Peter Lang.

Bonsignori, V., Bruti, S., \& Masi, S. (2012). Exploring greetings and leave-takings in original and dubbed language. In A. Remael, P. Orero and M. Carroll (Eds.), Audiovisual translation and media accessibility at the crossroads - Media for all 3 (pp. 357-379). Amsterdam : Editions Rodopi.

Bravo, D. (2008). The implications of studying politeness in Spanish-Speaking contexts: A discussion. Pragmatics, 18(4), 577-603.

Brown, P., \& Levinson, S. (1987). Politeness : Some universals in language usage. Cambridge: Cambridge University Press.

Bruti, S. (2006). Cross-cultural pragmatics: The translation of implicit compliments in subtitles. The Journal of Specialised Translation, 6, 185-197.

Byon, A. S. (2004). Sociopragmatic analysis of Korean requests: Pedagogical settings. Journal of Pragmatics, 36(9), 1673-1704.

Craven, A., \& Potter, J. (2010). Directives: Entitlement and contingency in action. Discourse Studies, 12(4), 419-442. 
Curl, T. S., \& Drew, P. (2008). Contingency and action: A comparison of two forms of requesting. Research on Language and Social Interaction, 41(2), 129-153.

De Pablos-Ortega, C. (2010). Attitudes of English speakers towards thanking in Spanish. Pragmatics, 20(2), 149-170.

De Pablos-Ortega, C. (2011). The pragmatics of thanking reflected in the textbooks for teaching Spanish as a foreign language. Journal of Pragmatics, 43(9), 2411-33.

De Pablos-Ortega, C. (2015). Thank you for a lovely day! Contrastive thanking in textbooks for teaching English and Spanish as foreign languages. Pragmática Sociocultural / Sociocultural Pragmatics, 3(2), 150-73.

De Pablos-Ortega, C. (2019). “I'm so sorry to disturb you but I wonder if I could have your autograph" versus "¿Me firma un autógrafo por favor" contrastive (In)directeness in subtitling. In R. Tipton, \& L. Desilla (Eds.), The Routledge handbook of translation and pragmatics routledge (chapter 11). United Kingdom: Taylor and Francis.

Desilla, L. (2012). Implicatures in film: Construal and functions in Bridget Jones romantic comedies. Journal of Pragmatics, 44(1), 30-53.

Dixon, S. (2015). Gimme! Gimme! Gimme!: Object requests, ownership and entitlement in a children's play session. Journal of Pragmatics, 82, 39-51.

Flores-Ferrán, N. (2010). An examination of mitigation strategies used in Spanish psychotherapeutic discourse. Journal of Pragmatics, 42(7), 1964-1981.

Gartzonika, O., \& Şerban, A. (2009). Greek soldiers on the screen: Politeness, fluency and audience design in subtitling. In J. Díaz Cintas (Ed.), New trends in audiovisual translation (pp. 239-250). Clevedon: Multilingual Matters.

González-Cruz, M. I. (2014). Request patterns by EFL Canarian Spanish students: Contrasting data by languages and research methods. Intercultural Pragmatics, 11(4), 547-573.

Grainger, K., \& Mills, S. (2016). Directness and indirectness across cultures. London: Palgrave Macmillan UK.

Greenall, A. K. (2011). Translating breaches of intersubjective constraints on interaction: The case of swearing in Roddy Doyle's novel the commitments. Meta Journal Des Traducteurs, 56(3), 538-556.

Grundy, P. (2008). Doing pragmatics. London: Hodder Education.

Haverkate, H. (1990). A speech act analysis of irony. Journal of Pragmatics, 14(1), 77-109.

Heinemann, T. (2006). 'Will you or can't you?': Displaying entitlement in interrogative requests. Journal of Pragmatics, 38(7), 1081-1104.

Hernández-Flores, N. (1999). Politeness ideology in Spanish colloquial conversation: The case of advice. Pragmatics, 9(1), 37-49.

Isnawati, F. D., Anam, S., \& Diana, S. (2015). Speech acts analysis of the main character in Shrek movie script analisis (Tindak Tutur Pada Tokoh Utama Di Dalam Naskah Film Shrek). Publika Budaya, 3(1), 60-64.

Kılıçkaya, F. (2010). The pragmatic knowledge of Turkish EFL students in using certain request strategies İngilizceyi Yabancı Dil Olarak (EFL) Öğrenen Türk Öğrencilerinin Belli İstek İzlemlerini Kullanmada Sahip Oldukları Edimsel Bilgi. Gaziantep University Journal of Social Sciences, 9(1), 185-201.

Kustantini, D. (2012). A Pragmatic Analysis Of Directive Speech Acts In Alice In Wonderland Movie Script (2010) (Doctoral dissertation, Universitas Muhammadiyah Surakarta).

Lindström, A. (2005). Language as social action. In A. Hakulinen \& M. Selting (Eds.), Syntax and lexis in conversation: Studies on the use of linguistic resources in talk-in interaction (pp. 209-230). Amsterdam: John Benjamins. 
Márquez-Reiter, R. (2000). Linguistic politeness in Britain and Uruguay. A contrastive study of requests and apologies. Pragmatics \& Beyond New Series, 83. Amsterdam: John Benjamins Publishing Company.

Monjour, A. (2006). Más allá de las fronteras de la descortesía: Intensificadores interdictos en el cine contemporáneo. RAEL, 5, 71-86.

Ogiermann, E. (2015). Direct off-record requests? -'Hinting' in family interactions. Journal of Pragmatics, 86, 31-35.

Pacheco Baldó, R. M. (2019). Impoliteness strategies and social characteristics. An analysis of films in Peninsular Spanish and American English speakers at work. Journal of Intercultural Communication Research, 48(6), 608-626.

Pedersen, J. (2008). High felicity: A speech act approach to quality assessment in subtitling. In D. Chiaro, C. Heiss \& C. Bucaria (Eds.), Between text and image: Updating research in screen translation (pp. 101-115). Amsterdam \& Philadelphia, PA: John Benjamins.

Piazza, R., Bednarek, M., \& Rossi, F. (2011). Telecinematic discourse: Approaches to the language of films and television series. Amsterdam/Philadelphia: John Benjamins.

Pinto, D. (2005). The acquisition of requests by second language learners of Spanish. Spanish in Context, 2(1), 1-27.

Pinto, D. (2010). Lost in subtitle translations: The case of advice in the english subtitles of spanish films. Intercultural Pragmatics, 7(2), 257-277.

Pinto, D., \& Raschio, R. (2007). A comparative study of requests in heritage speaker Spanish, L1 Spanish, and L1 English. International Journal of Bilingualism, 11(2), 135-55.

Placencia, M. E. (1996). Politeness in Ecuadorian Spanish. Multilingua - Journal of Cross-Cultural and Interlanguage Communication, 15(1), 13-34.

Placencia, M. E. (2008). (Non)Compliance with directives among family and friends: Responding to social pressure and individual wants. Intercultural Pragmatics, 5(3), 315-44.

Rossi, G. (2015). Responding to pre-requests: The organisation of Hai X 'Do You Have X' sequences in Italian. Journal of Pragmatics, 82, 5-22.

Schauer, G. A. (2006). Pragmatic awareness in ESL and EFL contexts: Contrast and development. Language Learning, 56(2), 269-318.

Searle, J. R. (1969). Speech acts. Cambridge: Cambridge University Press.

Searle, J. R. (1979). Expression and meaning: Studies in the theory of speech acts. Cambridge: Cambridge University Press.

Su, H. (2017). Local grammars of speech acts: An exploratory study. Journal of Pragmatics, 111, 72-83.

Takada, A., \& Endo, T. (2015). Object transfer in request-Accept sequence in Japanese Caregiverchild Interactions. Journal of Pragmatics, 82, 52-66.

Taylor, C. (2004). The language of film: Copora and statistics in the search for authenticity. Notting Hill (1998). A Case Study. Miscelanea, 30, 71-86.

Toribio, M. I. H., \& Escolar, L. D. (2014). Actos de cortesía valorizadora (cumplidos y halagos) en el cine argentino actual. Spanish in Context, 11(1), 97-116.

Usó-Juan, E. (2010). Requests: A sociopragmatic approach. In A. Martínez-Flor \& E. Usó-Juan (Eds.), Speech act performance: Theoretical, empirical and methodological issues (pp. 237-256). Amsterdam/Philadelphia: John Benjamins. 